\title{
Brevundimonas naejangsanensis sp. nov., a proteolytic bacterium isolated from soil, and reclassification of Mycoplana bullata into the genus Brevundimonas as Brevundimonas bullata comb. nov.
}

\author{
So-Jung Kang, ${ }^{1}$ Nack-Shick Choi, ${ }^{2}$ Jong Hyun Choi, ${ }^{2}$ Jung-Sook Lee, ${ }^{1}$ \\ Jung-Hoon Yoon ${ }^{1}$ and Jae Jun Song ${ }^{2}$ \\ ${ }^{1}$ Korea Research Institute of Bioscience and Biotechnology (KRIBB), PO Box 115, Yusong, Taejon, \\ Republic of Korea \\ ${ }^{2}$ Enzyme Based Fusion Technology Research Team, Jeonbuk Branch Institute, KRIBB, Jeonbuk \\ 580-185, Republic of Korea
}

Correspondence Jung-Hoon Yoon jhyoon@kribb.re.kr Jae Jun Song jjsong@kribb.re.kr

\begin{abstract}
A Gram-negative, motile and rod-shaped bacterial strain, BIO-TAS2- $2^{\top}$, of the class Alphaproteobacteria, was isolated from a soil in Korea and studied using a polyphasic taxonomic approach. Strain BIO-TAS2-2 ${ }^{\top}$ grew optimally at $\mathrm{pH} 7.5-8.5$ and $30{ }^{\circ} \mathrm{C}$ and in the presence of $0-1.0 \%(\mathrm{w} / \mathrm{v}) \mathrm{NaCl}$. A neighbour-joining phylogenetic tree based on 16S rRNA gene sequences showed that strain BIO-TAS2-2 ${ }^{\top}$ fell within the clade comprising species of the genus Brevundimonas, forming a coherent cluster with Brevundimonas terrae KSL-145 ${ }^{\top}$ and Brevundimonas diminuta LMG $2089^{\top}$. It exhibited $16 \mathrm{~S}$ rRNA gene sequence similarity values of 96.0-98.7\% to members of the genus Brevundimonas and Mycoplana bullata IAM $13153^{\top}$. Strain BIO-TAS2-2 ${ }^{\top}$ contained $\mathrm{Q}-10$ as the predominant ubiquinone and cyclo- $\mathrm{C}_{18: 1} \omega 7 \mathrm{c}$ and $\mathrm{C}_{16: 0}$ as the major fatty acids. The DNA G+C content was 67.0 mol\%. Strain BIO-TAS2-2 ${ }^{\top}$ exhibited DNA-DNA relatedness levels of 12-19\% with the type strains of phylogenetically related Brevundimonas species and $M$. bullata. The novel strain could be differentiated from Brevundimonas species and $M$. bullata by differences in phenotypic characteristics. On the basis of phenotypic, phylogenetic and genetic data, strain BIO-TAS2-2 ${ }^{\top}$ is considered to represent a novel species of the genus Brevundimonas, for which the name Brevundimonas naejangsanensis sp. nov. is proposed. The type strain is BIO-TAS2-2 ${ }^{\top}\left(=\right.$ KCTC $22631^{\top}=$ CCUG $\left.57609^{\top}\right)$. In this study, it is also proposed that Mycoplana bullata be transferred to the genus Brevundimonas as Brevundimonas bullata comb. nov. (type strain TK0051 ${ }^{\top}=$ ATCC $4278^{\top}=\mathrm{DSM} 7126^{\top}=\mathrm{JCM}$ $20846^{\top}=$ LMG $17157^{\top}$ ).
\end{abstract}

The genus Brevundimonas was proposed by Segers et al. (1994) and, at the time of writing, comprises 14 species with validly published names: $B$. diminuta and $B$. vesicularis (Segers et al., 1994), B. alba, B. aurantiaca, B. bacteroides, B. intermedia, B. subvibrioides and B. variabilis (Abraham et al., 1999), B. nasdae (Li et al., 2004), B. mediterranea (Fritz et al., 2005), B. kwangchunensis (Yoon et al., 2006a), B. terrae (Yoon et al., 2006b), B. aveniformis (Ryu et al., 2007) and B. lenta (Yoon et al., 2007). During the screening of

The GenBank/EMBL/DDBJ accession number for the 16S rRNA gene sequence of strain BIO-TAS2-2 ${ }^{\top}$ is FJ544245.

A supplementary table detailing the Biolog assimilation data for strain BIO-TAS2- $2^{\top}$ and related strains and an additional phylogenetic tree based on maximum-likelihood analysis of the 16S rRNA gene sequences are available with the online version of this paper. proteolytic micro-organisms from soil collected from Naejang Mountain in Korea, many novel bacterial strains have been isolated and characterized taxonomically. One of these isolates, designated BIO-TAS2 $-2^{\mathrm{T}}$, which had been found to be phylogenetically closely related to the genus Brevundimonas, is characterized in this study. The aim of the present work was to determine the exact taxonomic position of strain BIO-TAS2- $2^{\mathrm{T}}$ by using a polyphasic approach.

A soil sample collected from Naejang Mountain in Jeongeup, Korea, was used for the isolation of bacterial strains. Strain BIO-TAS2 $-2^{\mathrm{T}}$ was isolated by means of the standard dilution plating technique on Luria-Bertani (LB) agar containing $3 \%(\mathrm{w} / \mathrm{v})$ skim milk at $30{ }^{\circ} \mathrm{C}$. The type strains of two species of the genus Brevundimonas and 
Mycoplana bullata were used as reference strains for DNADNA hybridization. B. diminuta LMG $2089^{\mathrm{T}}$ was obtained from the Laboratorium voor Microbiologie Universiteit Gent (LMG; Gent, Belgium) and M. bullata DSM $7126^{\mathrm{T}}$ was obtained from the Deutsche Sammlung von Mikroorganismen und Zellkulturen (DSMZ; Braunschweig, Germany). B. terrae KSL- $145^{\mathrm{T}}$ was obtained from the study of Yoon et al. (2006b).

To investigate its morphological, physiological and biochemical characteristics, strain BIO-TAS2 $-2^{\mathrm{T}}$ was routinely cultivated on trypticase soy agar (TSA; Difco) at $30{ }^{\circ} \mathrm{C}$. Cell morphology was examined by light microscopy (E600; Nikon) using cells from exponentially growing cultures. The Gram reaction was determined using the bioMérieux Gram Stain kit according to the manufacturer's instructions. Growth at various temperatures $(4,10,20,25,28,30$, $35,40,45,50$ and $55{ }^{\circ} \mathrm{C}$ ) was measured on TSA. The $\mathrm{pH}$ range for growth was determined in nutrient broth (Difco) adjusted, prior to sterilization, to various $\mathrm{pH}$ values ( $\mathrm{pH} 4.5-10.5$ at intervals of $0.5 \mathrm{pH}$ units) by the addition of $\mathrm{HCl}$ or $\mathrm{Na}_{2} \mathrm{CO}_{3}$. Growth at various $\mathrm{NaCl}$ concentrations $(0,0.5,1.0,2.0,3.0,4.0$ and $5.0 \%$; w/v) was investigated using trypticase soy broth prepared according to the formula of the Difco medium except that $\mathrm{NaCl}$ was excluded. Growth under anaerobic conditions was determined after incubation in an anaerobic chamber on TSA and on TSA supplemented with potassium nitrate $(0.1 \%$, w/v), both of which had been prepared anaerobically under a nitrogen atmosphere. Catalase and oxidase activities and hydrolysis of gelatin, hypoxanthine, starch, Tweens 20,40 , 60 and 80, tyrosine, urea and xanthine were determined as described by Cowan \& Steel (1965). Hydrolysis of aesculin and nitrate reduction were examined as described previously (Lányí, 1987).

Susceptibility to antibiotics was tested by placing antibiotic-impregnated discs on TSA plates that were seeded with suspensions of the test strain. The concentrations of antibiotics used were as follows; polymyxin B (100 U), streptomycin $(50 \mu \mathrm{g})$, penicillin $\mathrm{G}(20 \mathrm{U})$, chloramphenicol $(100 \mu \mathrm{g})$, ampicillin $(10 \mu \mathrm{g})$, cephalothin $(30 \mu \mathrm{g})$, gentamicin $(30 \mu \mathrm{g})$, novobiocin $(5 \mu \mathrm{g})$, tetracycline $(30 \mu \mathrm{g})$, kanamycin $(30 \mu \mathrm{g})$, lincomycin $(15 \mu \mathrm{g})$, oleandomycin $(15 \mu \mathrm{g})$, neomycin $(30 \mu \mathrm{g})$ and carbenicillin $(100 \mu \mathrm{g})$. The assimilation of various substrates was determined by using the Biolog GN2 MicroPlate assay as recommended by the manufacturers. Enzyme activities and other physiological and biochemical properties were tested by using the API ZYM and API 20E systems (bioMérieux).

Cell biomass of strain BIO-TAS2-2 $2^{\mathrm{T}}$ for DNA extraction and for isoprenoid quinone analysis was obtained from cultures grown in trypticase soy broth (Difco) at $30{ }^{\circ} \mathrm{C}$. Chromosomal DNA was isolated and purified according to the method described by Yoon et al. (1996), with the exception that RNase T1 was used in combination with RNase A to minimize contamination with RNA. The $16 \mathrm{~S}$ rRNA gene was amplified by PCR using two universal primers as described previously (Yoon et al., 1998). Sequencing of the amplified 16S rRNA gene and phylogenetic analysis were performed as described by Yoon et al. (2003). Isoprenoid quinones were extracted according to the method of Komagata \& Suzuki (1987) and analysed using reversed-phase HPLC and a YMC ODS-A $(250 \times 4.6 \mathrm{~mm})$ column. For cellular fatty acid analysis, cell mass of strain BIO-TAS2 $-2^{\mathrm{T}}$ was harvested from TSA plates after incubation for 2 days at $30{ }^{\circ} \mathrm{C}$. The fatty acids were extracted and fatty acid methyl esters were prepared according to the standard protocol of the MIDI/Hewlett Packard Microbial Identification System (Sasser, 1990). The DNA G + C content was determined by the method of Tamaoka \& Komagata (1984) with the modification that DNA was hydrolysed and the resultant nucleotides were analysed by reversed-phase HPLC. DNA-DNA hybridization was performed fluorometrically by the method of Ezaki et al. (1989) using photobiotin-labelled DNA probes and microdilution wells. Hybridization was performed with five replications for each sample. The highest and lowest values obtained in each sample were excluded and the means of the remaining three values were quoted as DNA-DNA relatedness values.

The morphological, cultural, physiological and biochemical characteristics of strain BIO-TAS2-2 ${ }^{\mathrm{T}}$ are given in the species description (see below) or in Table 1. The almost complete 16S rRNA gene sequence of strain BIO-TAS2 $-2^{\mathrm{T}}$ determined in this study comprised 1418 nucleotides, representing approximately $96 \%$ of the Escherichia coli $16 \mathrm{~S}$ rRNA gene sequence. The phylogenetic analyses based on $16 \mathrm{~S}$ rRNA gene sequences revealed that strain BIO-TAS2- $2^{\mathrm{T}}$ fell within the clade comprising species of the genus Brevundimonas (Fig. 1). In the phylogenetic tree based on the neighbour-joining algorithm, strain BIO-TAS2-2 ${ }^{\mathrm{T}}$ joined the cluster comprising $B$. terrae and $B$. diminuta with a bootstrap resampling value of $77.7 \%$ (Fig. 1). This relationship was also maintained in trees constructed using the maximum-parsimony (Fig. 1) and the maximumlikelihood algorithms (see Supplementary Fig. S1 in IJSEM Online). Strain BIO-TAS2- $2^{\mathrm{T}}$ exhibited $16 \mathrm{~S}$ rRNA gene sequence similarity values of $98.0,98.7,96.8,96.6$ and $97.5 \%$ to the type strains of $B$. terrae, $B$. diminuta, B. lenta, $B$. subvibrioides and M. bullata, respectively, and 96.0-98.0\% to other Brevundimonas species used in the phylogenetic analysis.

The results obtained from chemotaxonomic analyses, showing the properties that are shared by species of the genus Brevundimonas, were in agreement with the result of phylogenetic analysis, i.e. that strain BIO-TAS2 $-2^{\mathrm{T}}$ is a member of the genus Brevundimonas. The predominant isoprenoid quinone detected in strain BIO-TAS2 $-2^{\mathrm{T}}$ was ubiquinone-10 (Q-10), as previously found for other Brevundimonas species (Segers et al., 1994; Abraham et al., 1999). The cellular fatty acid profile of strain BIOTAS2 $-2^{\mathrm{T}}$ is shown in Table 2, together with those of $B$. diminuta LMG $2089^{\mathrm{T}}$, B. terrae KSL- $145^{\mathrm{T}}$ and M. bullata DSM $7126^{\mathrm{T}}$, which were also analysed in this study. The 
Table 1. Differential phenotypic characteristics of strain BIO-TAS2-2 ${ }^{\top}$, phylogenetically related species of the genus Brevundimonas and M. bullata

Taxa: 1, strain BIO-TAS2-2 ${ }^{\mathrm{T}}$; 2, B. terrae (data from Yoon et al., 2006b); 3, B. diminuta (Palleroni, 1984; Segers et al., 1994; Li et al., 2004; Yoon et al., 2006a); 4, B. lenta (Yoon et al., 2007); 5, B. subvibrioides (Poindexter, 1964; Yoon et al., 2006a); 6, M. bullata (Urakami et al., 1990; Yoon et al., 2007). +, Positive; -, negative; w, weakly positive; ND, not determined; NG, no growth. Data in parentheses are for the type strain.

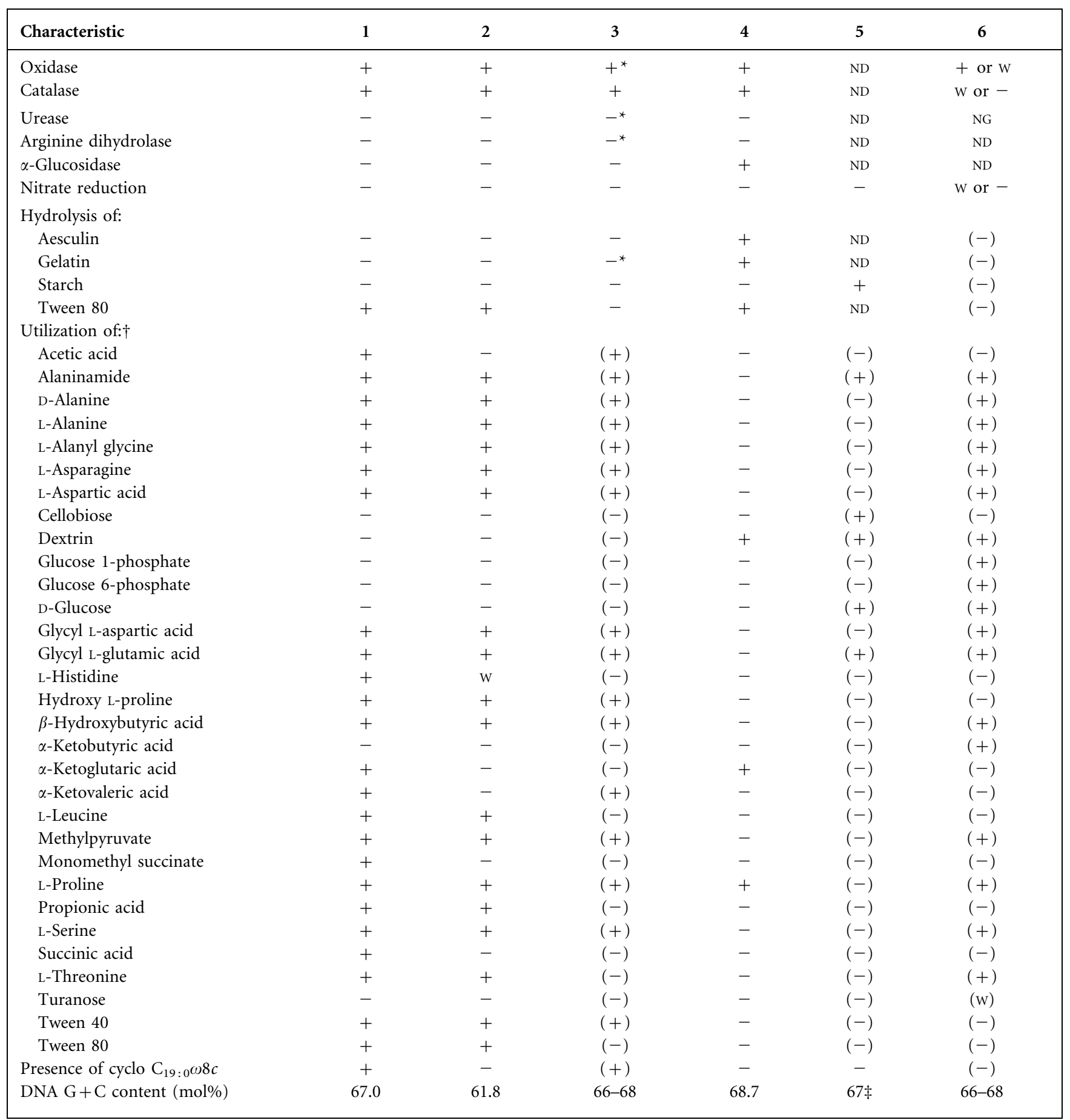

${ }^{\star}$ Data from Palleroni (1984) and Segers et al. (1994); different results for the type strains were obtained from Li et al. (2004).

$\dagger$ Data from Biolog GN2 MicroPlate assay for reference strains from Yoon et al. (2006a, b, 2007).

\$Determined for one isolate from Poindexter (1989). 


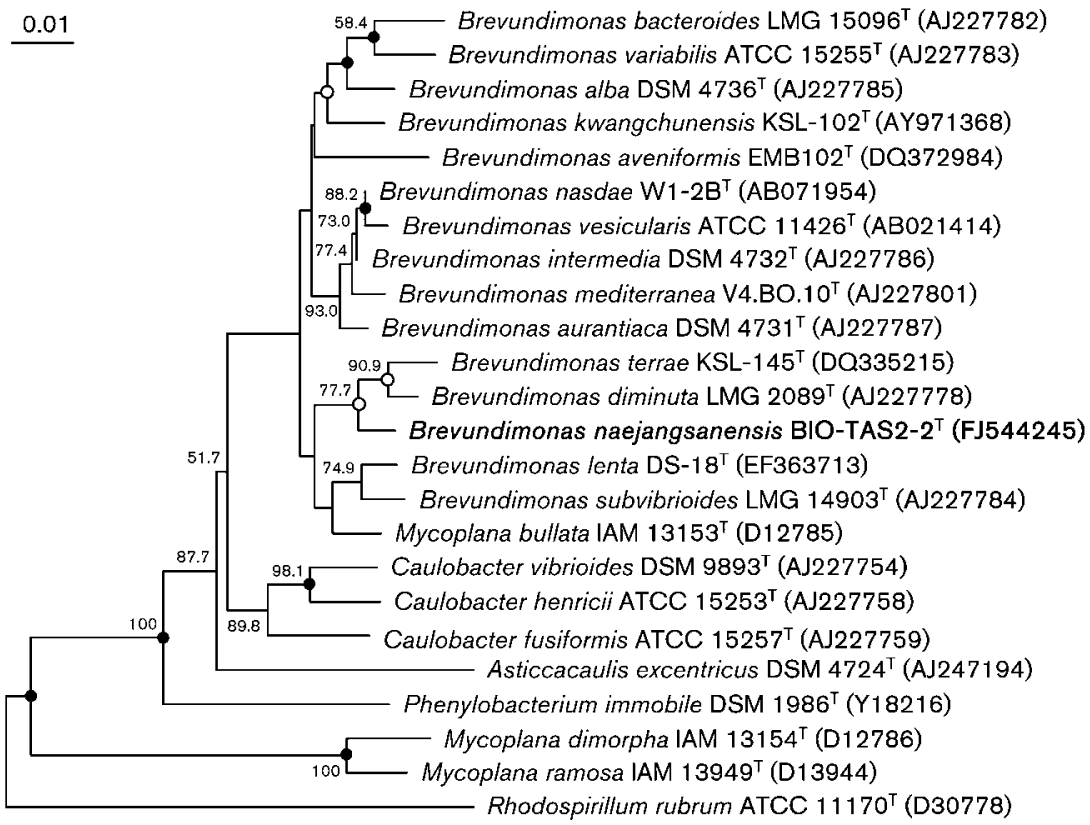

Fig. 1. Neighbour-joining phylogenetic tree based on 16S rRNA gene sequences showing the positions of strain BIO-TAS2- $2^{\top}$ and some other related taxa. Bootstrap values (expressed as percentages of 1000 replications) of $>50 \%$ are shown at branching points. Filled circles indicate that the corresponding nodes were also recovered in trees generated with both the maximum-likelihood and maximumparsimony algorithms. Open circles indicate that the corresponding nodes were recovered in the tree generated with the maximumparsimony algorithm. Rhodospirillum rubrum ATCC $11170^{\top}$ (GenBank accession no. D30778) was used as an outgroup. Bar, 0.01 substitutions per nucleotide position. major fatty acids ( $>10 \%$ total fatty acids) were $\mathrm{C}_{18: 1} \omega 7 \mathrm{c}$ and $\mathrm{C}_{16: 0}$. The fatty acid profiles of these species were similar, although there were differences in the proportions of some fatty acids between the taxa (Table 2). The DNA $\mathrm{G}+\mathrm{C}$ content of strain BIO-TAS2-2 ${ }^{\mathrm{T}}$ was $67.0 \mathrm{~mol} \%$.

Strain BIO-TAS2-2 ${ }^{\mathrm{T}}$ exhibited mean DNA-DNA relatedness levels of 12,19 and $17 \%$ to B. diminuta LMG $2089^{\mathrm{T}}$, B. terrae KSL- $145^{\mathrm{T}}$ and M. bullata DSM $7126^{\mathrm{T}}$, respectively, indicating that it is genetically different from these three reference strains (Wayne et al., 1987). Strain BIO-TAS2-2 ${ }^{\mathrm{T}}$ is distinguishable from recognized species of the genus Brevundimonas and M. bullata on the basis of differences in several phenotypic characteristics (Table 1 and Supplementary Table S1 in IJSEM Online). Therefore, this phylogenetic and genetic distinctiveness, together with the differential phenotypic properties, suggests that strain BIO-TAS2-2 ${ }^{\mathrm{T}}$ represents a novel species of the genus Brevundimonas, for which the name Brevundimonas naejangsanensis sp. nov. is proposed.

On the basis of the phylogenetic and chemotaxonomic data determined in this study, it is considered appropriate for M. bullata to be reclassified as a member of the genus Brevundimonas. The phylogenetic analyses based on $16 \mathrm{~S}$ rRNA gene sequences showed that M. bullata is phylogenetically more closely related to members of the genus Brevundimonas than to Mycoplana dimorpha IAM $13154^{\mathrm{T}}$, the type species of the genus, and Mycoplana ramosa IAM $13949^{\mathrm{T}}$ (Fig. 1; Yoon et al., 2006b). The results obtained from chemotaxonomic analyses revealed the properties that are shared by species of the genus Brevundimonas. M. bullata has previously been described as having Q-10 as the predominant ubiquinone (Urakami et al., 1990). The fatty acid profile of M. bullata DSM $7126^{\mathrm{T}}$ is similar to those of Brevundimonas species in that $\mathrm{C}_{18: 1} \omega 7 c$ and $\mathrm{C}_{16: 0}$ are the major fatty acids (Table 2; Urakami et al., 1990; Yoon et al., 2006b). Accordingly, it is proposed that Mycoplana bullata is transferred into the genus Brevundimonas as Brevundimonas bullata comb. nov.

\section{Description of Brevundimonas naejangsanensis sp. nov.}

Brevundimonas naejangsanensis (nae.jang.san.en'sis. N.L. fem. adj. naejangsanensis pertaining to Naejangsan, the Korean name of Naejang Mountain, from where the type strain was isolated).

Cells are Gram-negative and rod-shaped $(0.3-0.5 \times 0.7-$ $4.0 \mu \mathrm{m})$. Motile by means of a single polar flagellum. Colonies on TSA are circular, slightly convex, smooth, glistening, greyish yellow and $1.0-2.0 \mathrm{~mm}$ in diameter after incubation for 2 days at $30{ }^{\circ} \mathrm{C}$. Growth occurs at 4 and $50{ }^{\circ} \mathrm{C}$, but not at $55{ }^{\circ} \mathrm{C}$. Optimal pH for growth is between 7.5 and 8.5; growth occurs at $\mathrm{pH} 5.5$ and $\mathrm{pH} 10.0$, but not at $\mathrm{pH} 5.0$ or $\mathrm{pH}$ 10.5. Growth occurs in the presence of $0-4.0 \%(\mathrm{w} / \mathrm{v}) \mathrm{NaCl}$, with an optimum in the presence of $0-1.0 \% \quad(\mathrm{w} / \mathrm{v}) \mathrm{NaCl}$. Growth occurs under anaerobic conditions. Casein, L-tyrosine and Tweens 20,40 and 60 are hydrolysed, but hypoxanthine and xanthine are not. $\mathrm{H}_{2} \mathrm{~S}$ is not produced. Susceptible to chloramphenicol, gentamicin, kanamycin, neomycin, novobiocin, streptomycin and tetracycline, but not to ampicillin, carbenicillin, cephalothin, lincomycin, oleandomycin, penicillin $G$ or polymyxin B. In assays with the API ZYM system, alkaline phosphatase, esterase (C4), leucine arylamidase, valine arylamidase, trypsin, acid phosphatase and naphthol-ASBI-phosphohydrolase are present, but esterase lipase (C8), lipase (C14), cystine arylamidase, $\alpha$-chymotrypsin, $\alpha$ galactosidase, $\beta$-galactosidase, $\beta$-glucuronidase, $\beta$-glucosi- 
Table 2. Cellular fatty acid contents (\%) of strain BIO-TAS2-2 ${ }^{\top}$, the type strains of two Brevundimonas species and $M$. bullata

Strains: 1 , BIO-TAS2-2 ${ }^{\mathrm{T}} ; 2$, B. diminuta LMG $2089^{\mathrm{T}} ; 3$, B. terrae KSL$145^{\mathrm{T}} ; 4$, M. bullata DSM $7126^{\mathrm{T}}$. All data are from this study. - , Not detected. Fatty acids that represented $<0.5 \%$ in all strains were omitted.

\begin{tabular}{|lcccc|}
\hline Fatty acid & $\mathbf{1}$ & $\mathbf{2}$ & $\mathbf{3}$ & $\mathbf{4}$ \\
\hline Straight-chain fatty acid & & & & \\
$\mathrm{C}_{14: 0}$ & 0.9 & 0.6 & 3.3 & 1.0 \\
$\mathrm{C}_{15: 0}$ & 0.7 & 6.1 & 9.1 & 5.3 \\
$\mathrm{C}_{16: 0}$ & 25.3 & 15.5 & 24.7 & 21.2 \\
$\mathrm{C}_{17: 0}$ & 0.7 & 9.7 & 2.4 & 1.9 \\
Unsaturated fatty acid & & & & \\
$\mathrm{C}_{15: 1} \omega 8 c$ & - & 1.7 & 1.0 & 0.9 \\
$\mathrm{C}_{17: 1} \omega 6 c$ & 0.35 & 4.5 & 1.5 & 2.1 \\
$\mathrm{C}_{17: 1} \omega 8 c$ & 0.7 & 7.8 & 3.2 & 3.9 \\
$\mathrm{C}_{18: 1} \omega 5 c$ & 1.0 & 1.2 & 0.9 & 1.3 \\
$\mathrm{C}_{18: 1} \omega 7 c$ & 53.8 & 42.2 & 41.1 & 52.7 \\
$\mathrm{C}_{20: 2} \omega 6,9 c$ & 0.1 & 0.7 & - & - \\
Hydroxy fatty acid $_{\mathrm{C}_{12: 1} 3-\mathrm{OH}}$ & & & & \\
$\mathrm{C}_{12: 0} 3-\mathrm{OH}$ & 0.2 & 0.2 & 2.1 & 0.8 \\
11 -methyl C $18: 1 \omega 7 c$ & 2.2 & 1.7 & - & 1.6 \\
Cyclo $\mathrm{C}_{19: 0} \omega 8 c$ & 0.1 & - & 5.6 & 1.5 \\
Summed features & 9.5 & 5.4 & - & 0.2 \\
1 & & & & \\
3 & - & 0.8 & 0.3 & 0.2 \\
& 3.8 & 1.2 & 3.5 & 4.9 \\
\hline
\end{tabular}

${ }^{*}$ Summed features represent groups of two or three fatty acids which could not be separated by GLC with the MIDI system. Summed feature 1 contained iso- $\mathrm{C}_{15: 1}$ and/or $\mathrm{C}_{13: 0} 3-\mathrm{OH}$. Summed feature 3 contained $\mathrm{C}_{16: 1} \omega 7 c$ and/or iso- $\mathrm{C}_{15: 0} 2-\mathrm{OH}$.

dase, $N$-acetyl- $\beta$-glucosaminidase, $\alpha$-mannosidase and $\alpha$ fucosidase are absent. L-Glutamic acid is assimilated, but the following substrates are not assimilated: $\alpha$-cyclodextrin, glycogen, $N$-acetyl-D-galactosamine, $N$-acetyl-D-glucosamine, adonitol, L-arabinose, D-arabitol, i-erythritol, Dfructose, L-fucose, D-galactose, gentiobiose, myo-inositol, D-lactose, lactulose, maltose, D-mannitol, D-mannose, melibiose, methyl $\beta$-D-glucoside, D-psicose, raffinose, Lrhamnose, D-sorbitol, sucrose, trehalose, xylitol, cis-aconitic acid, citric acid, formic acid, D-galactonic acid lactone, D-galacturonic acid, D-gluconic acid, $\alpha$-hydroxybutyric acid, D-glucosaminic acid, D-glucuronic acid, $\gamma$-hydroxybutyric acid, $\rho$-hydroxyphenyl acetic acid, itaconic acid, DL-lactic acid, malonic acid, quinic acid, D-saccharic acid, sebacic acid, bromosuccinic acid, succinamic acid, glucuronamide, L-ornithine, L-phenylalanine, L-pyroglutamic acid, D-serine, DL-carnitine, $\gamma$-aminobutyric acid, urocanic acid, inosine, uridine, thymidine, phenylethylamine, putrescine, 2-aminoethanol, 2,3-butanediol, glycerol and DL- $\alpha$-glycerol phosphate. The predominant ubiquinone is
Q-10. The major fatty acids ( $>10 \%$ of total fatty acids) are $\mathrm{C}_{18: 1} \omega 7 c$ and $\mathrm{C}_{16: 0}$. Other phenotypic characteristics are given in Table 1.

The type strain, BIO-TAS2- $2^{\mathrm{T}}\left(=\right.$ KCTC $22631^{\mathrm{T}}=$ CCUG $57609^{\mathrm{T}}$ ), was isolated from a soil from Naejang Mountain, Korea. The DNA G+C content of the type strain is $67.0 \mathrm{~mol} \%$ (determined by HPLC).

\section{Description of Brevundimonas bullata comb. nov.}

Brevundimonas bullata (bull.a.ta. L. fem. adj. bullata wearing a bulla, with a knob).

Basonym: Mycoplana bullata Gray and Thornton 1928 (Approved Lists 1980) emend. Urakami et al. 1990.

The description is the same as that given by Urakami et al. (1990). The type strain is TK0051 ${ }^{\mathrm{T}}\left(=\right.$ ATCC $4278^{\mathrm{T}}=\mathrm{DSM}$ $7126^{\mathrm{T}}=\mathrm{JCM} 20846^{\mathrm{T}}=$ LMG $17157^{\mathrm{T}}$ ).

\section{Acknowledgements}

This work was supported by a HTS-based Integrated Technology Development grant (2008-04171) from the Ministry of Education, Science and Technology through the Korea Science and Engineering Foundation and a basic research grant from KRIBB.

\section{References}

Abraham, W.-R., Strömpl, C., Meyer, H., Lindholst, S., Moore, E. R. B., Christ, R., Vancanneyt, M., Tindall, B. J., Bennasar, A. \& other authors (1999). Phylogeny and polyphasic taxonomy of Caulobacter species. Proposal of Maricaulis gen. nov. with Maricaulis maris (Poindexter) comb. nov. as the type species, and emended description of the genera Brevundimonas and Caulobacter. Int J Syst Bacteriol 49, 1053-1073.

Cowan, S. T. \& Steel, K. J. (1965). Manual for the identification of medical bacteria. London: Cambridge University Press.

Ezaki, T., Hashimoto, Y. \& Yabuuchi, E. (1989). Fluorometric deoxyribonucleic acid-deoxyribonucleic acid hybridization in microdilution wells as an alternative to membrane filter hybridization in which radioisotopes are used to determine genetic relatedness among bacterial strains. Int J Syst Bacteriol 39, 224-229.

Fritz, I., Strömpl, C., Nikitin, D. I., Lysenko, A. M. \& Abraham, W.-R. (2005). Brevundimonas mediterranea sp. nov., a non-stalked species from the Mediterranean Sea. Int J Syst Evol Microbiol 55, 479-486.

Gray, P. H. H. \& Thornton, H. G. (1928). Soil bacteria that decompose certain aromatic compounds. Zentralbl Bakteriol Parasitenkd Infektionskr Hyg Abt II 73, 74-96.

Komagata, K. \& Suzuki, K. (1987). Lipid and cell-wall analysis in bacterial systematics. Methods Microbiol 19, 161-207.

Lányí, B. (1987). Classical and rapid identification methods for medically important bacteria. Methods Microbiol 19, 1-67.

Li, Y., Kawamura, Y., Fujiwara, N., Naka, T., Liu, H., Huang, X., Kobayashi, K. \& Ezaki, T. (2004). Sphingomonas yabuuchiae sp. nov. and Brevundimonas nasdae sp. nov., isolated from the Russian space laboratory Mir. Int J Syst Evol Microbiol 54, 819-825.

Palleroni, N. J. (1984). Genus Pseudomonas Migula 1894. In Bergey's Manual of Systematic Bacteriology, vol. 1, pp. 141-199. Edited by N. R. Krieg \& J. G. Holt. Baltimore: Williams \& Wilkins. 
Poindexter, J. S. (1964). Biological properties and classification of the Caulobacter group. Bacteriol Rev 28, 231-295.

Poindexter, J. S. (1989). Genus Caulobacter Henrici and Johnson 1935. In Bergey's Manual of Systematic Bacteriology, vol. 3, pp. 19241939. Edited by J. T. Staley, M. P. Bryant, N. Pfennig \& J. G. Holt. Baltimore: Williams \& Wilkins.

Ryu, S. H., Park, M., Lee, J. R., Yun, P.-Y. \& Jeon, C. O. (2007). Brevundimonas aveniformis sp. nov., a stalked species isolated from activated sludge. Int J Syst Evol Microbiol 57, 1561-1565.

Sasser, M. (1990). Identification of bacteria by gas chromatography of cellular fatty acids, MIDI Technical Note 101. Newark, DE: MIDI Inc.

Segers, P., Vancanneyt, M., Pot, B., Torck, U., Hoste, B., Dewettinck, D., Falsen, E., Kersters, K. \& De Vos, P. (1994). Classification of Pseudomonas diminuta Leifson and Hugh 1954 and Pseudomonas vesicularis Büsing, Döll, and Freytag 1953 in Brevundimonas gen. nov. as Brevundimonas diminuta comb. nov. and Brevundimonas vesicularis comb. nov., respectively. Int J Syst Bacteriol 44, 499-510.

Tamaoka, J. \& Komagata, K. (1984). Determination of DNA base composition by reverse-phase high-performance liquid chromatography. FEMS Microbiol Lett 25, 125-128.

Urakami, T., Oyanagi, H., Araki, H., Suzuki, K.-I. \& Komagata, K. (1990). Recharacterization and emended description of the genus Mycoplana and description of two new species, Mycoplana ramosa and Mycoplana segnis. Int J Syst Bacteriol 40, 434-442.
Wayne, L. G., Brenner, D. J., Colwell, R. R., Grimont, P. A. D., Kandler, O., Krichevsky, M. I., Moore, L. H., Moore, W. E. C., Murray, R. G. E. \& other authors (1987). International Committee on Systematic Bacteriology. Report of the ad hoc committee on reconciliation of approaches to bacterial systematics. Int J Syst Bacteriol 37, 463-464.

Yoon, J.-H., Kim, H., Kim, S.-B., Kim, H.-J., Kim, W. Y., Lee, S. T., Goodfellow, M. \& Park, Y.-H. (1996). Identification of Saccharomonospora strains by the use of genomic DNA fragments and rRNA gene probes. Int J Syst Bacteriol 46, 502-505.

Yoon, J.-H., Lee, S. T. \& Park, Y.-H. (1998). Inter- and intraspecific phylogenetic analysis of the genus Nocardioides and related taxa based on 16S rRNA gene sequences. Int J Syst Bacteriol 48, 187-194.

Yoon, J.-H., Kang, K. H. \& Park, Y.-H. (2003). Psychrobacter jeotgali sp. nov., isolated from jeotgal, a traditional Korean fermented seafood. Int J Syst Evol Microbiol 53, 449-454.

Yoon, J.-H., Kang, S.-J., Oh, H. W., Lee, J.-S. \& Oh, T.-K. (2006a). Brevundimonas kwangchunensis sp. nov., isolated from an alkaline soil in Korea. Int J Syst Evol Microbiol 56, 613-617.

Yoon, J.-H., Kang, S.-J., Lee, J.-S. \& Oh, T.-K. (2006b). Brevundimonas terrae sp. nov., isolated from an alkaline soil in Korea. Int J Syst Evol Microbiol 56, 2915-2919.

Yoon, J.-H., Kang, S.-J., Lee, J.-S., Oh, H. W. \& Oh, T.-K. (2007). Brevundimonas lenta sp. nov., isolated from soil. Int J Syst Evol Microbiol 57, 2236-2240. 